\title{
Interpreting Differences in Parental Encouragement to learn the host language: California and Catalonia Compared
}

\author{
Ann Elizabeth Wilson, Universitat Autònoma de Barcelona/ University of Barcelona, Spain
}

(Article received 29 June 2012; final version received 01 September 2012)

\begin{abstract}
This article is based on a subset of data gathered in a bi-national $\mathrm{PhD}$ study regarding measures of parental encouragement when comparing immigrant background and native students $(n=233)$ in Catalonia (Spain) and California. The ANOVA means comparisons of parental encouragement based on groupings of first generation, second generation, and native students show a decrease in parental encouragement (over immigrant generations) among the Californian respondents but an increase among the Catalan respondents. It is hypothesized that in Catalonia, newcomer parents realize over a period of years importance of the Catalan language in Catalonia, in contrast, in the US, parents of newcomer students arrive aware of the importance of learning English. Nevertheless, more data is needed to confirm this hypothesis. Results are combined with a review of recent literature in order to argue the need for more studies on immigrant parent attitudes as perceived by their children toward L2 learning, especially in Catalonia.
\end{abstract}

\section{Introduction}

For many decades, researchers have been aware of the influence that parental encouragement, or lack thereof, can have on an individual's motivation to learn a L2 (e.g. Feenstra, 1969; Colletta, Clément, \& Edwards, 1983; Gardner, 1968, 1985; Gardner, Masgoret \& Tremblay, 1999; Sung \& Padilla, 1998; Vijchulata \& Lee, 1985). Futhermore, many recent research projects on language learning motivation have included this factor in their studies (see, for example, Atay \& Kurt, 2010; Csizér \& Kormos, 2009; Henkel, 2009; Kormos, Kiddle, \& Csizér, 2011; Matsuzaki Carreira, 2011; Ryan, 2009; Taguchi, Magid, \& Papi, 2009). Nevertheless, few studies have specifically considered immigrant parental attitudes or encouragement toward L2 language learning, or immigrant students' perception of their parents’ attitudes.

\section{Contexts: Catalonia and California}

Most studies on immigration and language learning focus on contexts where one language clearly dominates (Pujolar, 2010) and is easily identified as the high status language, as is 
the case with English in the US. In officially bilingual Catalonia, however, newly arriving immigrant parents and their children may find themselves in a situation where the dominant language is not always evident. Officially, in schools, Catalan is used as the primary language of instruction, but teachers may address recently arrived students in Spanish, sending mixed messages to these students, placing them in a "space of sociolinguistic segregation” (Pujolar, 2010, p. 231). Immigrants in Catalonia are required to adjust to “different, competing, often blatantly contradictory linguistic ideologies and practices” (Pujolar, 2010, p. 230, citing Schieffelin, Kroskrity, \& Woolard, 1998). On the other hand, in the US, immigrant students and their parents tend to arrive already convinced of the importance of learning English (Suárez-Orozco, C., Suárez-Orozco, M., \& Todorova, 2008).

Non-European immigration is a recent phenomenon in Catalonia which started in the early 1980s; percentages began to increase significantly in 1996 (Dooly \& Unamuno, 2009; Deusdad Ayala, 2009). According to the Catalan government's official statistics, the overall percentage of immigrant residents in Catalonia jumped from 3\% to 15\% in the last decade and approximately 70\% percent of this immigration comes from outside of Europe (IDESCAT, 2008; 2011). Gibson, Carrasco, Pàmies, Ponferrada and Rios (in press) also compare Californian and Catalan contexts in their study of immigrant background students. As these authors point out, Spain recently became second to the United States in annual immigration, with Catalonia accounting for 21\% of Spain’s total immigrant population.

The recent increase of immigrant background students in Catalan school systems makes studies of this group of timely relevance. In the words of Dooly and Unamuno (2009) Catalonia is "in the midst of coming to terms with the integration of multiple languages, cultures, ethnicities, and religions stemming from recent immigration of people of European and non-European origins” (p. 218). On the other hand, California has a much longer history of non-European immigration. It is also currently the US state with the highest rate of immigration (Rumbaut, 2008).

In the United States, research has shown that home/heritage language death among immigrant background Americans is all but inevitable by the third generation; however, many of these individuals refuse to speak and/or learn the language even earlier (Portes \& 
Rumbaut, 2006; Rumbaut, Massey, \& Bean, 2006; Fishman, 1966). Nevertheless, since non-European immigration is a new to Catalonia, phenomenon like dual-official language assimilation and home language death and/or maintenance among these immigrant generations is more difficult to gauge. That makes studies on immigrant language attitudes in Catalonia that much more relevant.

\section{Parental Encouragement and language learning motivation}

One of the most well-known figures in the area of language learning motivation is R. C. Gardner whose seminal work changed the way experts in the field looked at language learning. Years of work developed into what is known as the Socio-educational Model (Gardner, 1985, 2010). A parental encouragement construct has been included in many of the studies that Gardner and his colleagues have carried out over the last four decades (see also Gardner, Masgoret \& Tremblay, 1999). Gardner argues that parental influence can manifest itself either actively by encouraging the student to do well in the language class, and/or passively, by openly questioning or supporting the utility of learning the language or by expressing negative or positive attitudes toward the people/groups that speak the language (2010, p. 128). He claims that parents may or may not see the utility of learning a language and potentially pass that sentiment on to their children; even though they might see its usefulness regarding a specific aspect such as getting into a college or university or getting good grades.

Successive models of language learning motivation have also included the role of parental encouragement and that of other significant people in learners' lives (Williams \& Burden, 1997; Noels, 2001). Dörnyei, who initially did not include a salient parental encouragement component in earlier models of language learning motivation (Dörnyei, 1994, 2000; Dörnyei \& Otto, 1998), has recognized its importance in his more recently proposed L2 Motivational Self System Theory where he calls it "parents' influence" (2005). However, Henkel (2009), in her study of Hungarian minority students in the Ukraine, found that parental encouragement correlated significantly with the Ought-to L2 Self component ${ }^{1}$ in Dörnyei’s motivational self-system and concluded that students' 
Ought-to L2 Self might really manifest itself as the Ought-to L2 Self that their parents hope for and likewise convey to their children.

Other research over the years has demonstrated the relationship between attitudes and motivation and the level of parental encouragement (i.e. Coletta, Clément, \& Edwards, 1983; Skehan, 1989). However, few recent, comprehensive studies have focused only on parental encouragement regarding language learning. In a tri-national, mixed methods comparison of high school students in England, Germany, and the Netherlands $(n=411)$, Bartram (2006) found a clear association between students' perceived parent attitudes toward language learning and students' own attitudes. The most important influence he found was the way parent attitudes aided in constructing students' understanding of "language importance, utility and status" (p. 220).

\section{Immigrant background students and Parental encouragement to learn a language}

Torres-Guzmán, Etxeberría-Sagastume, and Intxausti Intxausti (2011) interviewed 26 immigrant parents in the Basque Country whose children attended a Model D Euskara (Basque language) immersion school. ${ }^{2}$ They found that, overall, multilingual immigrant parents were more supportive of their children learning Euskara than monolingual parents. They also discovered that immigrant parents' motivation toward their children learning Euskara was tied to their perception of the language's immediate utility (p. 44).

Bernaus, Masgoret, Gardner, and Reyes (2004) studied the effect of immigrant students' 'cultural' background regarding their motivation and attitudes to learn three different languages. With measures drawn from the Socio-educational Model through the corresponding mini-AMTB, they found that participants who felt that their parents encouraged them to learn one language also considered their parents to be supportive in learning other languages. They also found that the children of Asian parents (speakers of Punjabi, Urdu, Chinese, Tagalog, and Bangladeshi) reported less parental encouragement regarding learning the Catalan language than Spanish or English. Other groups were not found to report a significantly higher level of parental encouragement for one language than another. 


\section{This study}

Recognizing the value of motivation in language learning (see, for example, Dörnyei, 2001; Gardner, 1985; 2010; Skehan, 1989), many scholars, including many of the aforementioned, have attempted to gain insight into how language learners are motivated by studying this construct through models of language learning motivation. For this paper, the Socio-educational (SE) Model (Gardner, 1985, 2010) and an adaptation of the miniAMTB (Bernaus \& Gardner, 2008) were used to identify possible factors affecting plurilingual or potentially plurilingual students' attitudes and motivation toward the languages they study and/or speak. Although the data presented in this article is one small part of the data gathered for a much larger research project, it is considered that the findings presented here warrant further study.

\section{Participants}

Two high schools in Catalonia and one larger high school in California, all with high densities of immigrant students, were selected for participation in this study. The immigrant background students from all three schools came from a geographically diverse range of countries of origin. The participants who completed the survey sufficiently enough for analysis were as follows:

- 116 students from a high school in Central California (United States), School I

- 117 students from two high schools in Catalonia:

i. $\quad 71$ students from School II

ii. $\quad 46$ students from School III

School I is located in a large urban school district in Central California near the center of a mid-sized city located in California's Central Valley. School II, located in a densely populated city on the outskirts of Girona. School III in downtown Barcelona’s Ciutat Vella caters to a student population with a larger number of immigrant background students than the other two schools.

\section{Procedure}

Participants completed a questionnaire containing the following four sections: 1) sociodemographic questions, some of which were based on questions taken from Ibarraran, 
Lasagabaster, and Sierra (2007), 2) an adapted and translated version of the mini-AMTB (Bernaus \& Gardner, 2008), 3) a Can-do self-rating evaluation (Clark, 1984) for student self-evaluation of language ability, and 4) four general, open-ended questions on students’ motivation and attitudes.

The mini-AMTB and Can-do Scales were originally developed for collecting information from participants on only one language. However, as the current study was designed to investigate participant perceptions of up to four languages, it was necessary to review and revise the original format of both instruments and slightly alter them in a way appropriate both for the number of languages and for the language contexts under study. A column format was developed in which the students addressed each item (see Wilson, 2012).

The main procedure in all three contexts was similar; the items were both read aloud to the students by the dissertation supervisor in the Catalan contexts and by the author in the California context, as well as simultaneously read by students on paper. Clarifications and repetitions were made when necessary. Questionnaire administration in all cases, including a brief oral introduction to the study, took an entire class period of 50 minutes.

\section{Data Analysis}

The data presented in this article were analyzed via one-way analyses of variance (ANOVA), which were carried out in order to determine if significant differences existed between groups of first generation, second generation, and native participants. These groups were defined in accordance with the OECD (2006) definitions of first-generation (immigrant) students and second-generation (immigrant) students. According to this organization, first-generation students were born, along with their parents, outside of the country in which they currently reside. Second-generation students were born in the current country of residence but have parents who were born in a different country. Native students are considered students who were not only born in the country in which they currently reside but also have at least one parent born in that country (OECD, 2006).

Parental encouragement to learn English was analyzed in California (Table 1) and to learn Catalan in Catalonia (Table 2). In both contexts these languages represented the principal language of instruction.

Bellaterra Journal of Teaching \& Learning Language \& Literature. 5.3

(Aug-Sept 2012): 44-56. ISSN 2013-6196. 


\section{Results and Discussion}

According to the ANOVA results for the California sample, as Table 1 illustrates, there was a significant difference among the means of all three groups regarding parental encouragement concerning the institutional language of instruction (English). The analyses revealed that among the Californian participants in this study, first generation students reported significantly higher parental encouragement than second generation and native students. Second generation students reported higher levels of parental encouragement than native students, but lower than first generation students, whereas the native students reported significantly lower parental encouragement regarding the learning of the English language than first and second generation students. These results indicate that in California, the perceived amount of parental encouragement decreases as immigration generations progress.

\section{TABLE 1}

Parental encouragement to learn English (California) -Results of a One-Way ANOVA

\begin{tabular}{lccccc}
\hline \hline Groups & $N$ & & Mean & \multicolumn{2}{c}{ Between-Component Variance } \\
\hline $1^{\text {st }}$ generation & 32 & 4.63 & & .135 & \\
$2^{\text {nd }}$ generation & 23 & 4.09 & & & \\
Native & 61 & 3.89 & & & Sig. \\
\hline Source of Variation & $S S$ & $d f$ & $M S$ & 5.742 & .004 \\
\hline Between groups & 11.538 & 2 & 5.769 & & \\
Within groups & 113.523 & 113 & 1.005 & & \\
Total & 125.060 & 115 & & & \\
\hline
\end{tabular}

However, the results in Catalonia (see Table 2) regarding the institutional language of instruction, Catalan, show a different pattern. Unlike with the Californian participants, the reported mean for parental encouragement to learn Catalan among the first generation students was lower than that of their second generation and native peers. The second generation students reported higher parental encouragement towards learning Catalan than the first generation students and lower than the native students. Overall, the native students reported the highest level of parental encouragement in Catalonia. 
TABLE 2

Parental encouragement to learn Catalan (Catalonia) -Results of a One-Way ANOVA

\begin{tabular}{|c|c|c|c|c|c|c|}
\hline Groups & $N$ & & Mean & \multicolumn{3}{|c|}{ Between-Component Variance } \\
\hline $1^{\text {st }}$ generation & 53 & & 3.79 & & .089 & \\
\hline $2^{\text {nd }}$ generation & 18 & & 4.17 & & & \\
\hline Native & 46 & & 4.41 & & & \\
\hline Source of Variation & SS & $d f$ & & MS & $F$ & Sig. \\
\hline Between groups & 9.597 & 2 & & 4.798 & 3.033 & .052 \\
\hline Within groups & 180.369 & 114 & & 1.582 & & \\
\hline Total & 189.966 & 116 & & & & \\
\hline
\end{tabular}

These findings suggest that as immigrant background students in the US master the language, the level of perceived parental encouragement diminishes. However, the opposite occurs in Catalonia; probably due to an increase realization on behalf of the parents of the utility of the Catalan language. As seen in other recent studies (Bartram, 2006; TorresGuzmán, Etxeberría-Sagastume, \& Intxausti Intxausti, 2011) the perception of the utility of a language plays an important role in parental encouragement to learn that language. Based on the literature review and the data presented here, it is hypothesized that in Catalonia, newcomer parents do not necessarily realize upon arrival, nor shortly thereafter, the utility of Catalan in Catalonia and the central role it plays in the school system of their children; nevertheless, this author proposes that after they have resided in Catalonia a while, parents gradually come to realize its importance. Still, further study is needed to determine the empirical validity of this hypothesis.

\section{Conclusions}

Numerous studies have demonstrated that in the United States, the English language has a clear status and utility that is perceived before and/or upon arrival by immigrant students and their parents (Suárez-Orozco, C., Suárez-Orozco, M., \& Todorova, 2008). In Catalonia, on the other hand, depending on factors such as location or arrival, class, parent's profession; the perceived presence and importance of the Catalan language can vary (Pujolar, 2010; Woolard, 1989). Nevertheless, in the case of the perception of parents in this study, it seems that the awareness of the utility of Catalan may become more evident as 
they spend more time in the host country or territory when immigrants' immediate needs for survival are met and issues like class mobility become more evident.

The pedagogical implications of these findings are that teachers in Catalonia should be aware of this possible delay in parental encouragement on the part of immigrant parents. Special effort should be made in aiding parents to understand that language competence in the language of instruction is fundamental for school success. Furthermore, although perhaps not evident to some immigrant parents, the Catalan language is prevalent in the university system and in many higher-status jobs. Perhaps the communication of the utility of Catalan in Catalonia would be facilitated through outreach meetings with immigrant parents from the same country or region of origin who have spent more time in the host country.

As evidenced by the large number of studies and language learning motivation models cited in this article that claim that Parental Encouragement is directly related to student motivation, it is a factor that warrants attention both at a practical, day-to-day school level and in future research. As Dooly, Vallejo, and Unamuno (2009) point out, the period of time in which the immigrant background student takes to learn the language of instruction can have long-term detrimental effects caused by de-motivation when they are continuously and unfairly evaluated in an inferior way in comparison to their peers, resulting in a lack of confidence and long-term self-esteem issues. They argue that discriminatory practices can also have negative effects on attitudes toward their H/HL and, in extreme cases, can cause the student to suffer elective mutism. Knowing what factors influence the parental perception of language importance, utility, and status can better help language teachers, administrators, community members, and researchers understand language learning motivation in potentially plurilingual individuals.

\section{Suggestions for Future Research}

The data presented in this study is limited in that it is drawn from an instrument that is not exclusively designed to measure parental encouragement. Moreover, the study is not experimental in character. Future research in this area should include a longitudinal analysis of parental attitudes toward L2 learning both from students' and parents' perspectives. This type of research project would provide valuable comparative data that 
might aid in the understanding of the evolution of parental attitudes over time. As emphasized earlier, given that little research has been carried out on Parental Encouragement in Catalonia, parent and student interviews and surveys could be aimed at learning more about the process that these parents go through in accepting (or not) the importance of Catalan and encouraging their children to learn it, and by confirming or contrasting this pattern in other contexts and/or with other language categories.

Future, larger scale studies would ideally include schools of varying typology, taking into account the following: the percentage of immigrant students per school, languages spoken in the school, languages prevalent and available in the community, sociocultural characteristics of the families that attend the schools, age of students, and the private/public character and urban/ rural characteristics of the schools.

\section{References}

Atay, G., \& Kurt, D. (2010). The socio-educational model of second language acquisition: The Turkish context. Procedia - Social and Behavioral Sciences, 2, 3088-3093.

Bartram, B. (2006). An examination of perceptions of parental influence on attitudes to language learning. Educational Research, 48, 211-221.

Bernaus, M., \& Gardner, R. C. (2008). Teacher Motivation Strategies, Student Perceptions, Student Motivation, and English Achievement. The Modern Language Journal, 92, 387-401.

Bernaus, M., Masgoret, A.-M., Gardner, R. C., \& Reyes, E. (2004). Motivation and attitudes toward learning languages in multicultural classrooms. International Journal of Multilingualism, 1, 75-89.

Cenoz, J. (2009). Towards Multilingual Education: Basque Educational Research from an International Perspective. Bristol: Multilingual Matters.

Clark, J. D. (1984). Language. In T. S. Barrows (Ed.), A survey of global understanding: Final report (pp. 87-100). New York: Change Magazine Press.

Colletta, S. P., Clement, R., \& Edwards, H. P. (1983). Community and parental influence: Effects on student motivation and French second language proficiency. Quebec, Canada: International Center for Research on Bilingualism.

Csizér, K., \& Kormos, J. (2009). Modelling the role of inter-cultural contact in the motivation of learning English as a foreign language. Applied Linguistics, 30, 166185.

Dooly, M., \& Unamuno, V. (2009). Multiple languages in one society: categorisations of language and social cohesion in policy and practice. Journal of Education Policy, 24 (3), 217-236.

Dooly, M., Vallejo, C., \& Unamuno, V. (2009). Educational Policies that Address Social Inequality. Linguistic Minority Thematic Report. EU Commissioned Report.

London: Institute for Policy Studies in Education. 
Dörnyei, Z. (2005). The Psychology of the Language Learner: Individual Differences in Second Language Acquisition. London: Lawrence Erlbaum Associates.

Dörnyei, Z. (1994). Motivation and motivating in the foreign language classroom. The Modern Language Journal, 78, 273-85.

Dornyei, Z. (2000). Motivation in action: Toward a process-oriented conceptualisation of student motivation. British Journal of Educational Psychology, 70, 519-538.

Dörnyei, Z. (2001). Teaching and researching motivation. Essex: Pearson Education.

Dörnyei, Z., \& Ottó, I. (1998). Motivation in action: A process model of L2 motivation. Working Papers in Applied Linguistics, 4, 43-69.

Feenstra, H. J. (1969). Parent and teacher attitudes: Their role in second-language acquisition. Canadian Modern Language Review, 26, 5-13.

Fishman, J. A. (Ed.). (1966). Language loyalty in the United States: the maintenance and perpetuation of non-English mother tongues by American ethnic and religious groups. The Hague: Mouton.

Gardner, R. C. (1968). Attitudes and motivation: Their role in second-language acquisition. TESOL Quarterly, 2, 141-150.

Gardner, R. C. (1985). Social Psychology and Second Language Learning: The Role of Attitudes and Motivation. London: Edward Arnold.

Gardner, R. C. (2010). Motivation and Second Language Acquisition: The SocioEducational Model. New York: Peter Lang Publishing, Inc.

Gardner, R. C., Masgoret, A-M., \& Tremblay, P. F. (1999). Home background characteristics and second language learning. Journal of Language and Social Psychology, 18, 419-437.

Gibson, M., Carrasco, S., Pàmies, J., Ponferrada, M., \& Rios, A. (in press). Different Systems, similar results. Immigrant Youth in schools in California and Catalonia. In The Children of Immigrants in Schools in the US and the EU, R. Alba \& J. Holdaway, (Eds.) New York: New York University Press.

Henkel, B. (2009). Motivation to learn a second language for minority students. Practice and Theory in Systems of Education, 4 (2), 63-78.

Higgins, E. T. (1987). Self-discrepancy: A theory relating self and affect. Psychological Review, 94, 319-340.

Higgins, E. T. Klein, R., \& Strauman, T. (1985). Self-concept discrepancy theory: A psychological model for distinguishing among different aspects of depression and anxiety. Social Cognition, 3, 51-76.

Ibarraran, A., Lasagabaster, D., \& Sierra J. M. (2007). Inmigración y aprendizaje de lenguas en un contexto bilingüe. Bilbao: LETE Argitaletxea.

IDESCAT (2008). La immigració, ara i aquí Catalunya 2008. Dades estadístiques. Retrieved from http://www.idescat.cat/cataleg/?tc=c\&idp=79

IDESCAT (2011). Anuari estadístic de Catalunya: Població estrangera. Barcelona: Generalitat de Catalunya. Retrieved from http://www.idescat.cat/poblacio estrangera/?b=0

Kormos, J., Kiddle, T., \& Csizér, K. (2011). Systems of Goals, Attitudes, and Self-related Beliefs in Second-Language-Learning Motivation. Applied Linguistics, 32 (5), 495516. 
Matsuzaki-Carreira, J. (2011). Relationship between motivation for learning EFL and intrinsic motivation for learning in general among Japanese elementary school students. System, 39 (1), 90-102.

Noels, K. A. (2001). New orientations in language learning motivation: Toward a contextual model of intrinsic, extrinsic, and integrative orientations and motivation. In Z. Dornyei \& R. Schmidt (Eds.), Motivation and second language acquisition (pp. 43-68). Honolulu: University of Hawaii Second Language Teaching and Curriculum Center.

OECD (2006). Where immigrant students succeed - A comparative review of performance and engagement. Paris: OECD.

Portes, A., \& Rumbaut, R. G. (2006). Immigrant America: A portrait (3rd ed.). Berkeley: University of California Press.

Pujolar, J. (2010). Immigration and Language Education in Catalonia: Between National and Social Agendas. Linguistics and Education, 21 (3), 229-243.

Rumbaut, R. G. (2008). The Coming of the Second Generation: Immigration and Ethnic Mobility in Southern California. ANNALS of the American Academy of Political and Social Science 620, 196-236.

Rumbaut, R. G., Massey, D. S., \& Bean, F. D. (2006). Linguistic Life Expectancies: Immigrant Language Retention in Southern California. Population and Development Review, 32, 447-60.

Ryan, S. (2009). Self and identity in L2 motivation in Japan: The Ideal L2 self and Japanese, learners of English. In Z. Dörnyei \& E. Ushioda (Eds.). Motivation, language identity and the L2 self (pp. 120-141). Clevedon, UK: Multilingual Matters.

Schieffelin, B. B., Kroskrity, P. V., \& Woolard, K. A. (1998). Language ideologies: Practice and theory. Oxford: Oxford University Press.

Skehan, P. (1989). Individual Differences in Second-Language Learning. London, Edward Arnold.

Suárez-Orozco, C., Suárez-Orozco, M., \& Todorova, I. (2008). Learning a new land: Immigrant students in American society. Cambridge, MA: Harvard University Press.

Sung, H., \& Padilla, A. M. (1998). Student motivation, parental attitudes, and involvement in the learning of Asian languages in elementary and secondary schools. The Modern Language Journal, 82 (2), 205-16.

Taguchi, T., Magid, M., \& Papi, M. (2009). The L2 motivational self-system among Japanese, Chinese and Iranian learners of English: A comparative study. In Z. Dörnyei \& E. Ushioda (Eds.). Motivation, language identity and the L2 self (pp. 6697). Clevedon, UK: Multilingual Matters.

Torres-Guzmán, M. E., Etxeberría-Sagastume, F. \& Intxausti Intxausti, N. (2011). “El Euskera a Mi Me Gusta”: Parental Attitudes of Basque Country Immigrants. The New Educator, 7 (1), 44-65.

Vijchulata, B., \& Lee, G. (1985). A survey of students' motivation for learning English. RELC Journal, 16 (1), 68-81.

Williams, M., \& Burden, R. (1997). Psychology for language Teachers. New York: Cambridge University Press. 
Wilson, A. (2012). Language Learning Motivation and Attitudes among Immigrant Background Students: A mixed method approach comparing three secondary school contexts. Unpublished PhD dissertation, Universitat Autònoma de Barcelona.

Woolard, K. A. (1989). Doubletalk: Bilingualism and the politics of ethnicity in Catalonia. Stanford: Stanford University Press.

\footnotetext{
${ }^{1}$ Dörnyei (2009) defines the Ought-to L2 Self as a representation of attributes that a learner believes he or she ought to possess, in other words, a sense of duty or obligation externally imposed by others (p. 13, 29). He bases this definition on a similar concept put forth by Higgins decades ago (1987; Higgins, Klein, \& Strauman, 1985).

${ }^{2}$ Currently, Basque Country residents with school-aged children can choose between three different school types: in Model A schools all classes are taught in Spanish, apart from Basque language subjects; Model B schools offer their students bilingual immersion in both Basque and Spanish; and in Model D schools all classes are taught in Basque apart from Spanish language subjects (see also Cenoz, 2009 and Ibarraran, Lasagabaster, and Sierra, 2007). Therefore, immigrant parents who opt to send their children to a Model D school are likely more open to their children learning the Basque language than parents who send their children to other school types.
}

\section{Author's Reference:}

Ann Elizabeth Wilson is currently a research fellow at the department of Social Science Teaching Methodology, Universitat de Barcelona.

Email: awilson@ub.edu

To cite this article:

Wilson, A.E. (2012). Interpreting differences in parental encouragement to learn the host language: California and Catalonia compared. Bellaterra Journal of Teaching \& Learning Language \& Literature, 5(3), 44-56. 